\title{
Effect of supplementation with vegetable oil on performance of lactating Awassi ewes, growth of their lambs and on fatty acid profile of milk and blood of lambs
}

\author{
Hosam H. Titi and Abdur-Rahman Al-Fataftah \\ Department of Animal Production, Faculty of Agriculture, University of Jordan, Amman, Jordan
}

\begin{abstract}
The present study investigated the effects of supplementing soybean oil (SBO) and sunflower oil (SFO) on the performance of early lactating Awassi ewes, growth of their sucking lambs and on the concentration of total fatty acids in milk and blood of suckling lambs. One hundred and twenty five ewes were randomly assigned into five equal sized treatment groups involved; a control total mixed ration (TMR) without added oil and four diets supplemented with $3 \%$ $\mathrm{SBO}, 5 \% \mathrm{SBO}, 3 \% \mathrm{SFO}$ or $5 \% \mathrm{SFO}$.

Milk yield increased $(P<0.05)$ in ewes fed $3 \%$ SBO and $5 \%$ SFO compared to control ewes. Milk protein content increased $(P<0.05)$ in $3 \%$ SBO, $3 \%$ SFO and $5 \%$ SFO groups in comparison to the control and $5 \%$ SBO groups, whereas crude protein yield increased $((P<0.05)$ in $3 \%$ and $5 \%$ SFO groups compared to the control group. Plasma content of cholesterol in lamb was increased $(P<0.05)$, while that of triglycerides was reduced $(P<0.05)$. Supplementation with both oils reduced $(P<0.05)$ short and medium chain fatty acids in milk fat but increased $(P<0.05) C 16: 0, C 17: 1$ and C18:0 content in milk fat. Supplementation also increased $(P<0.05)$ the cis-9 trans-11 conjugated linoleic acid (CLA) content in milk fat. However, SFO produced higher $(P<0.05)$ values than SBO. Both oils led to more $(P<0.05)$ total CLA in the plasma of suckling lambs. In conclusion, supplementing a moderate dose of SBO or SFO to the diets increased CLA concentration in milk fat. Nevertheless, supplementation with SFO was more effective than that with SBO in increasing CLA concentration in milk fat and improving milk quality from the human health standpoint.
\end{abstract}

Keywords: ewes, lambs, soybean oil, sunflower oil, milk production, milk composition, fatty acid profile, CLA 
Abbreviations: ADF: acid detergent fibre; ADG: average daily gain; BW: body weight; CLA: conjugated linoleic acid; CP: crude protein; CRD: completely randomised design; DM: dry matter; DMI: dry matter intake; ECM: energy corrected milk; EE: ether extract; FA: fatty acid; FAMEs: fatty acid methyl esters; ME: metabolizable energy; MEl: metabolizable energy intake; MEV: milk energy value; MFD: milk fat depression; NDF: neutral detergent fibre; PUFA: poly unsaturated fatty acids; SBO: soybean oil; SEM: standard error of mean; SFO: sunflower oil; TMR: total mixed ration

\section{Introduction}

Sheep milk is very important in human health. In the Middle East, fat content of such milk is an important component for the nutritional quality of milk products and might limit the demand for this milk and/or its products by health conscious consumers and has been criticised to contribute for the development of hypercholesterolemia, atherosclerosis and other cardiovascular health problems (Zhang et al. 2006a, b).

Over the past 15 years, a vast amount of research has examined the effect of dietary components with particular interest in effects of dietary oil supplements (Reynolds et al. 2006). Much of the research attempted to obtain milk fat with healthier properties by increasing milk concentration of specific human health promoting fatty acids. Although mechanisms of action are unclear and its use in humans is controversial, conjugated linoleic acid (CLA) is still of particular interest because of its speculated role in preventing human health problems and increasing the nutritive and therapeutic value of milk (Cieslak et al. 2010).

Fat supplementation of the diet is an efficient mean to modify milk yield, fat content and fatty acid (FA) composition in lactating ruminants (Chilliard et al. 2003). Feeding vegetable oils has been shown to affect milk yield and composition, as well as FA and CLA content of milk in cows and goats (Castro et al. 2009). Plant oils from different oilseeds have different FA compositions and accordingly have different effects on milk FA profile (Gómez-Cortés et al. 2008).

The number of studies on sheep milk as responded to added fat is rather limited compared to studies on cows and goats (Chilliard et al. 2003, Reynolds et al. 2006, Hervás et al. 2008). Much of the research with fat supplementation at sheep has been taken to assess the effect of protected forms to lactating ewes on milk yield and composition (Zhang et al. 2006b, Gómez-Cortés et al. 2008, Castro et al. 2009). At the same time, unprotected oils rich in poly unsaturated fatty acids (PUFA) like sunflower oil (SFO) or soybean oil (SBO) are rarely used in ruminant diets as they are proposed to impair ruminal function (Castro et al. 2009). Few studies have also been carried out on dairy ewes given dietary oils with regards to how milk from such ewes affects suckling lamb FA composition (Lurueña-Martinez et al. 2010). Changes in milk FA composition can induce differences in FA composition of suckling lambs. Therefore, the objective of this study was to determine the effect of supplementing lactating Awassi ewes with soybean oil or sunflower oil on their milking performance, growth of their lambs and FA composition of milk and blood of lambs.

\section{Material and methods}

Animals and diets

This experiment was carried out during the lambing season of the year 2010/2011 at the Agricultural Research Station, University of Jordan in the Jordan Valley. The research station 
is at an altitude of $-244 \mathrm{~m}$ (below sea level) and a latitude of $32^{\circ} 13^{\wedge} \mathrm{N}$. A total of 125 freshly lactating Awassi ewes were used in this study that lasted 60 days. Initial body weight ranged from 50 to $0 \pm 1.36 \mathrm{~kg}$ and age from 2.5 to 4 years. The experiment started exactly after lambing and all females had given birth at least once before they were used in the experiment. Ewes were randomly assigned into one of five dietary treatment groups ( $25 \mathrm{ewes} /$ treatment) in a completely randomised design (CRD). Diets were offered as a total mixed ration (TMR) that included; control ration without oil supplementation (Control), control ration supplemented with $3 \%$ soybean oil (SBO) ( $3 \% \mathrm{SBO})$, control ration supplemented with $5 \% \mathrm{SBO}(5 \% \mathrm{SBO})$, control ration supplemented with $3 \%$ sunflower oil (SFO) (3\% SFO) and a control ration supplemented with 5\% SFO (5\% SFO). Diets were formulated according to NRC (2007). Percentage of supplemented oil in the diet was calculated as a percent of barley content in the ration.

Ewes were fed individually $(1.5 \times 1.5 \mathrm{~m})$ at a rate of $1.5 \mathrm{~kg}$ per head per day from the TMR and had ad libitum access to alfalfa hay. Alfalfa hay consumed daily was measured on individual basis and clean drinking water was provided. Animals were maintained at ambient temperature and natural day length in covered-seal yards with an open side. Rations were mixed twice weekly and daily allowances were offered for all animals once at 7:00 a.m. Lambs were left with dams from birth to the end of the experimental period with no access to the TMR but with free access to water.

\section{Feed, milk and blood sampling}

Composite feed samples were taken each week after mixing for each treatment and kept frozen for chemical analysis. Milk production was measured individually once weekly using double oxytocin injection and hand milking procedure (Reynolds et al. 2006). Ewes received two intravenous injections of $2 \mathrm{ml}$ oxytocin each (Oxytocin, Alfasan, Worden, Holland) with $4 \mathrm{~h}$ interval. Milk production within this interval period was evaluated using a graduated cylinder $( \pm 5 \mathrm{ml})$. The amount of milk obtained was adjusted for $24 \mathrm{~h}$ on weekly basis. An individual milk sample was taken weekly for composition analysis from each dam. Samples were preserved with $2-3 \mathrm{ml}$ of potassium dichromate and stored at $4^{\circ} \mathrm{C}$ until further analysis.

Blood samples were obtained at the 6th and 8th week from the jugular vein of each lamb in each treatment into heparinized tubes and centrifuged at $3000 \times \mathrm{g}$ for $15 \mathrm{~min}$. The obtained plasma was stored at $-20^{\circ} \mathrm{C}$ until fat separation and FA analysis. Serum cholesterol and triglycerides were determined using automated enzymatic procedure (Merck-Mexico and IA for cholesterol and triglyceride respectively) (Espinoza et al. 1997).

\section{Chemical analysis}

Feed samples were ground through a 1-mm screen and analysed for dry matter (DM), crude protein (CP), ether extract (EE) and ash (Table 1; AOAC 1995). Neutral detergent fibre (NDF) and acid detergent fibre (ADF) were analysed according to Geohring \& Van Soest (1970) using the ANKOM ${ }^{200 / 220}$ Fibre Analyser (ANKOM Technology Corp., Fairport, NY, USA). Analysis of NDF was performed with sodium sulphite and a heat stable amylase and expressed with residual ash. Content of NDF and ADF was expressed with residual ash. 
Table 1

Ingredient composition and chemical composition of the experimental diets ${ }^{1}$

\begin{tabular}{|c|c|c|c|c|c|}
\hline Ingredients & Control & $3 \%$ SBO & $5 \%$ SBO & $3 \%$ SFO & $5 \%$ SFO \\
\hline Barley & 60 & 60 & 60 & 60 & 60 \\
\hline Soybean meal & 13 & 13 & 13 & 13 & 13 \\
\hline Alfalfa hay & 10 & 10 & 10 & 10 & 10 \\
\hline Straw & 5 & 5 & 5 & 5 & 5 \\
\hline Wheat bran & 10 & 10 & 10 & 10 & 10 \\
\hline Oil & 0 & 1.8 & 3 & 1.8 & 3 \\
\hline Di-calcium phosphate & 1 & 1 & 1 & 1 & 1 \\
\hline Salt & 0.4 & 0.4 & 0.4 & 0.4 & 0.4 \\
\hline Limestone & 0.5 & 0.5 & 0.5 & 0.5 & 0.5 \\
\hline Mineral and vitamin mix² & 0.1 & 0.1 & 0.1 & 0.1 & 0.1 \\
\hline \multicolumn{6}{|l|}{ Chemical composition } \\
\hline Dry matter, \% & 87.9 & 88.5 & 88.5 & 88.5 & 88.8 \\
\hline Crude protein, $\%$ & 16.3 & 15.8 & 15.9 & 16.1 & 16.0 \\
\hline Ether extract, \% & 2.7 & 4.3 & 5.4 & 4.2 & 5.5 \\
\hline NDF, $\%$ & 38.5 & 42.5 & 39.3 & 38.1 & 41.2 \\
\hline$A D F, \%$ & 8.6 & 8.3 & 9.1 & 8.3 & 8.7 \\
\hline Ash, \% & 6.5 & 7.5 & 6.1 & 5.5 & 6.4 \\
\hline $\mathrm{ME}, \mathrm{MJ} \backslash \mathrm{kg}^{3}$ & 10.59 & 11.11 & 11.62 & 11.10 & 11.63 \\
\hline
\end{tabular}

${ }^{1} \mathrm{All}$ results are expressed based on dry matter basis, ${ }^{2}$ Vita-M premix (DADvet, Na'ur, Jordan) each 1 gram contains: 1500 I.U. Vitamin A, 150 I.U. vitamin D3, 2 mg Vitamin E 50\%, $300 \mu \mathrm{g}$ vitamin B1, $300 \mu \mathrm{g}$ vitamin B2, 300 $\mu \mathrm{g}$ vitamin B6, $300 \mu \mathrm{g}$ vitamin K3 50\%, $218 \mu \mathrm{g}$ Manganese Oxide, $435 \mu \mathrm{g}$ Ferrous Sulfate, $15.5 \mu \mathrm{g}$ Cupper Oxide, $138.5 \mu \mathrm{g}$ Zinc Oxide, $2.2 \mu \mathrm{g}$ Potassium lodide, $0.9 \mu \mathrm{g}$ Sodium Selinate, $0.43 \mu \mathrm{g}$ Cobalt Carbonate, $\mathrm{CaCO}_{3}$ reach $1 \mathrm{~g},{ }^{3}$ calculated using NRC (2007)

Milk samples were analysed for fat (Gerber method), protein $(\mathrm{N} \times 6.38)$ and total solids using standard procedures of AOAC (1995). Energy corrected milk (ECM, kg/d) was estimated as: milk $(\mathrm{kg}) \times(0.071 \times$ fat $(\%)+0.043 \times$ protein $(\%)+0.2224)$, (Castro et al. 2009). Milk energy value (MEV,

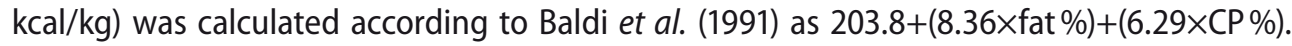
Body weight of dams was taken at lambing and once again at the end of the experiment. Birth weight of lambs was recorded at birth while weaning weight was measured at $60 \mathrm{~d}$ post-lambing.

\section{Lipid extraction}

Milk lipids were extracted following the Roese-Gottlib method (AOAC 1995). Plasma total lipid extraction was carried out following the procedure of Loor et al. (2002). Fatty acids were extracted and methylated following the method described by Castro et al. (2009).

Fatty acid profile and CLA were determined for blood and milk fat samples using capillary GC column (Rtx-225, Restek, USA, crossbond 70\%-cyanopropylmethyl 50\%-phenylmethyl polysiloxane, $60 \mathrm{~m}, 0.25 \mathrm{~mm} / \mathrm{D}, 0.25 \mu \mathrm{m} \mathrm{df}$ ). The fatty acid methyl esters (FAMEs) were identified using a chromatogram of fatty acids standard (Supelco37 FAMEs mix C4-C24, Sigma-Aldrich, St. Louis, MO, USA). Standard of CLA (Sigma linoleic acid, conjugated methyl esters, Sigma-Aldrich, St. Louis, MO, USA) was also used and injected separately in the GC under the same conditions. The FAMEs were injected after the $\mathrm{GC}$ conditions were adjusted; column oven temperature was $70^{\circ} \mathrm{C}$ for $1 \mathrm{~min}$, increased to $165^{\circ} \mathrm{C}$ at rate of $20^{\circ} \mathrm{C} / \mathrm{min}$ and kept at $165^{\circ} \mathrm{C}$ for $8 \mathrm{~min}$, increased to $180^{\circ} \mathrm{C}$ at $1{ }^{\circ} \mathrm{C} / \mathrm{min}$ and kept at $180^{\circ} \mathrm{C}$ for $1 \mathrm{~min}$, then 
increased to $220^{\circ} \mathrm{C}$ at $3{ }^{\circ} \mathrm{C} / \mathrm{min}$ and kept at $220^{\circ} \mathrm{C}$ for $10 \mathrm{~min}$. Temperature of injector and detector was $260^{\circ} \mathrm{C}$ and flow rate was $1.0 \mathrm{ml} / \mathrm{min}$. Helium as carrier gas and 1:60 split ratio were used (Castro et al. 2009).

\section{Statistical analysis}

Milk yield and composition, MEV, as well as FAs and CLA were analysed using the proc mix procedure of SAS v. 7 (SAS Institute Inc., Cary, NC, USA) in a CRD with repeated measures. The independent values included treatment (oil source and level), replicate (ewe), period (time of sampling; day or week) and their interactions. Blood analysis results and daily gain of lambs were analysed in a CRD arrangement (SAS v7). Model utilised included treatment, sex and there interactions as independent variables, while birth weight of lamb and lambing weight of dams were used as covariates during analysis. Least square means were separated for significances $(P<0.05)$ according to Fisher protected LSD (Steel \& Torrie 1980).

\section{Results and discussion}

\section{Milk production and composition}

ANOVA results showed no interaction response. Therefore, the main effects are presented herein. Daily milk yield and energy corrected milk $(E C M)(\mathrm{kg} / \mathrm{d})$ were higher $(P<0.05)$ for ewes fed oil supplemented diets (Table 2) with maximum daily yield for 3\% SBO and 5\% SFO ewes. However, ewes in the $5 \%$ SBO and $3 \%$ SFO groups had a milk production similar to the control ewes. Supplemental fat oils increased milk yield of lactating ewes (Reynolds et al. 2006, Zhang et al. 2006a, b, Castro et al. 2009, Cieslak et al. 2010). Contrary to these findings, milk production was not affected by fat oil treatment when given to lactating ewes (Hervás et al. 2008, Manso et al. 2011).

Table 2

Milk production and milk composition of Awassi ewes fed different levels of SBO and SFO in their ration

\begin{tabular}{lcccccc}
\hline & Control & $3 \%$ SBO & $5 \%$ SBO & $3 \%$ SFO & $5 \%$ SFO & SEM \\
\hline Milk production, kg/d & $1.38^{\mathrm{b}}$ & $2.18^{\mathrm{a}}$ & $1.84^{\mathrm{ab}}$ & $1.66^{\mathrm{ab}}$ & $2.12^{\mathrm{a}}$ & 0.28 \\
ECM, kg/d & $1.28^{\mathrm{c}}$ & $2.15^{\mathrm{a}}$ & $1.74^{\mathrm{b}}$ & $1.58^{\mathrm{bc}}$ & $1.80^{\mathrm{ab}}$ & 0.17 \\
Fat, \% & $7.00^{\mathrm{a}}$ & $7.60^{\mathrm{a}}$ & $7.20^{\mathrm{a}}$ & $7.43^{\mathrm{a}}$ & $5.55^{\mathrm{b}}$ & 0.35 \\
Fat, g/d & $95.9^{\mathrm{b}}$ & $171.6^{\mathrm{a}}$ & $132.3^{\mathrm{ab}}$ & $118.6^{\mathrm{b}}$ & $116.0^{\mathrm{b}}$ & 20.4 \\
Protein, \% & $4.76^{\mathrm{b}}$ & $5.25^{\mathrm{a}}$ & $4.87^{\mathrm{b}}$ & $5.11^{\mathrm{a}}$ & $5.10^{\mathrm{a}}$ & 0.12 \\
Protein, g/d & $70.20^{\mathrm{b}}$ & $114.70^{\mathrm{a}}$ & $90.60^{\mathrm{ab}}$ & $83.50^{\mathrm{ab}}$ & $107.50^{\mathrm{a}}$ & 14.6 \\
Total solids, \% & $18.30^{\mathrm{a}}$ & $16.80^{\mathrm{a}}$ & $15.84^{\mathrm{b}}$ & $15.70^{\mathrm{b}}$ & $14.93^{\mathrm{b}}$ & 0.46 \\
MEV, kcal/kg & 293.60 & 300.17 & 294.66 & 298.10 & 282.18 & 3.02 \\
\hline
\end{tabular}

${ }^{a b c}$ Means with different superscripts within the same raw are different $(P<0.05), E C M=m i l k(k g) \times(0.071 \times f a t(\%)+0.043 \times$ protein(\%)+0.2224), (Castro et al. 2009). MEV=203.8+(8.36×fat\%)+(6.29×CP\%), (Baldi et al. 1992)

Milk yield is directly attributed to energy intake by the higher energy content of the oil supplemented diet (Castro et al. 2009, Cieslak et al. 2010, Manso et al. 2011). According to Chilliard et al. (2003), supplemental fat is a mean for increasing energy intake and efficiency in early lactation in ruminants. However, results from early-lactation experiments are limited by their lack of precision linked to possible differences in milk potential of animals and 
limited use of covariates. Differing responses of milk yield to dietary fat may relate in part to the genetic potential of the ewes for milk yield, the supply of energy from the basal diet and the effects of the dietary fat on dry matter intake (DMI) and nutrient partitioning (Reynolds et al. 2006, Manso et al. 2011). Published literature concerning the effect of fat supplementation on ECM of lactating ewes is scarce. However, Castro et al. (2009) observed increased ECM for ewes supplemented with vegetable oil but the response varied with source.

Contents of milk fat were not affected by treatments (Table 2) contrary to those of milk protein that were increased $(P<0.05)$ with oil supplementation. Fat yield $(\mathrm{g} / \mathrm{d})$ was only increased $(P<0.05)$ in milk of ewes fed the $3 \%$ SBO while protein yield was higher $(P<0.05)$ in ewes fed either $3 \%$ SBO or $5 \%$ SFO diet. Milk energy values ( $\mathrm{Kcal} / \mathrm{kg}$ ) were consistent among groups.

The rate of PUFA release into the rumen seems to be more crucial implying that fats with high rumen degradation like SFO might have more detrimental impact on milk fat proportion mainly due to the inhibition of the de novo synthesis or through production of biohydrogenation intermediates in the rumen by the PUFA of the supplemented fat (Zhang et al. 2006a, Toral et al. 2010). This might explain the drop in milk fat content of ewes fed the $5 \%$ SFO diet.

\section{Dry matter intake, Body weights}

No differences were observed in total DMI expressed in $\mathrm{kg} / \mathrm{d}$ or in concentrate and hay intake as separates (Table 3 ). Values were mostly related to changes in alfalfa hay intake because the intake of the concentrate ration was fixed among groups $(1.5 \mathrm{~kg} / \mathrm{d})$. On the other hand, the intake of metabolisable energy and the feed to milk ratio $(\mathrm{kg} / \mathrm{kg})$ were higher $(P<0.05)$ with oil addition as well as with the level of oil added.

Table 3

Feed intake and body weights of Awassi ewes fed different levels of SBO or SFO in their rations

\begin{tabular}{lcccccc}
\hline & & \multicolumn{1}{c}{ Diets } & & \\
& Control & $3 \%$ SBO & $5 \%$ SBO & 3\% SFO & $5 \%$ SFO & SEM \\
\hline No. of Animals & 25 & 25 & 25 & 25 & 25 & 25 \\
Feed intake, kg DM/hd/d & 2.20 & 2.21 & 2.24 & 2.25 & 2.22 & 0.03 \\
Ration & 1.5 & 1.5 & 1.5 & 1.5 & 1.5 & 1.5 \\
Hay & 0.70 & 0.71 & 0.74 & 0.75 & 0.72 & 0.02 \\
MEl, MJ/hd/d & $23.30^{\mathrm{c}}$ & $24.60^{\mathrm{b}}$ & $26.03^{\mathrm{a}}$ & $24.98^{\mathrm{b}}$ & $25.82^{\mathrm{a}}$ & 0.18 \\
Feed:Milk & $1.60^{\mathrm{d}}$ & $1.01^{\mathrm{a}}$ & $1.22^{\mathrm{b}}$ & $1.36^{\mathrm{c}}$ & $1.05^{\mathrm{a}}$ & 0.02 \\
Initial BW & 63.8 & 66.5 & 66.5 & 66.9 & 65.2 & \\
Final BW & 64.6 & 67.0 & 67.2 & 67.5 & 66.3 & 3.1 \\
BW change & $0.8^{\mathrm{ab}}$ & $0.5^{\mathrm{b}}$ & $0.7^{\mathrm{ab}}$ & $0.6^{\mathrm{b}}$ & $1.1^{\mathrm{a}}$ & 0.05 \\
\hline
\end{tabular}

${ }^{a b c}$ Means with different superscripts within the same raw are different $(P<0.05)$. Feed:Milk=daily intake:daily milk production, $\mathrm{kg} / \mathrm{kg}$, BW change=final BW - initial BW

The increased intake of metabolisable energy is the main reason behind the increased milk yield with oil level. Gómes-Cortés et al. (2008) concluded that increased milk was due to greater energy content of the oil supplemented diets and not by a greater DMI. This would be confirmed by the strong relationship between energy intake and milk yield (Zhang et al. 2006a, Cieslak et al. 2010). 
Initial body weights of ewes were used as covariate for the analysis of final body weights. Yet, no differences were observed in final body weight of ewes among different groups (Table 3). This increase in body weight throughout the experimental period would suggest that animals were on average under a positive energy balance and that energy and protein provided by all diets were adequate to meet the requirements for milk production.

\section{Growth rate of lambs and Blood metabolites}

Weaning weights, average daily gain (ADG) and total average daily gain of lambs born to ewes of the experiment were practically unchanged among experimental groups (Table 4). Birth weight of lambs was used as covariate during growth analysis. Weaning weights of suckling lambs and their ADG before weaning were not affected by different oil sources supplemented in their diets (Manso et al. 2011, Berthelot et al. 2012).

Table 4

Weaning weight, weight gain, and blood metabolites lambs of Awassi ewes fed different levels of SBO or SFO in their rations

\begin{tabular}{|c|c|c|c|c|c|c|}
\hline & Control & $3 \%$ SBO & $5 \%$ SBO & $3 \%$ SFO & $5 \%$ SFO & SEM \\
\hline Number of lambs & 29 & 32 & 30 & 29 & 31 & \\
\hline Birth weight, kg & 4.30 & 4.60 & 3.82 & 4.27 & 3.91 & 0.24 \\
\hline Weaning weight, kg & 19.34 & 20.10 & 18.15 & 18.75 & 18.70 & 0.98 \\
\hline Male & 20.80 & 20.50 & 18.10 & 20.00 & 18.53 & 1.28 \\
\hline Female & 17.90 & 19.70 & 18.23 & 17.50 & 18.80 & 1.57 \\
\hline Average gain, kg & 15.00 & 15.50 & 14.33 & 14.48 & 14.79 & 0.99 \\
\hline Average daily gain, $\mathrm{kg} / \mathrm{d}$ & 0.25 & 0.26 & 0.24 & 0.24 & 0.25 & 0.01 \\
\hline Male & $0.26^{\mathrm{ab}}$ & $0.27^{\mathrm{a}}$ & $0.23^{b}$ & $0.26^{\mathrm{ab}}$ & $0.24^{\mathrm{ab}}$ & 0.01 \\
\hline Female & 0.23 & 0.25 & 0.24 & 0.22 & 0.25 & 0.02 \\
\hline Milk conversion ratio ${ }^{1}$ & $3.40^{\mathrm{a}}$ & $3.62^{\mathrm{a}}$ & $4.10^{\mathrm{ab}}$ & $3.76^{\mathrm{a}}$ & $4.35^{\mathrm{b}}$ & 0.22 \\
\hline Male & $3.25^{\mathrm{a}}$ & $3.57^{\mathrm{a}}$ & $4.26^{b}$ & $3.62^{\mathrm{ab}}$ & $4.57^{\mathrm{b}}$ & 0.31 \\
\hline Female & 3.57 & 3.67 & 3.93 & 3.90 & 4.13 & 0.34 \\
\hline \multicolumn{7}{|l|}{ Blood metabolites, mmol/l } \\
\hline Cholesterol & $95^{b}$ & $90^{b}$ & $132^{\mathrm{a}}$ & $132^{\mathrm{a}}$ & $93^{b}$ & 1.88 \\
\hline Triglycerides & $101^{\mathrm{a}}$ & $66^{d}$ & $74^{c}$ & $86^{b}$ & $71^{c}$ & 1.79 \\
\hline
\end{tabular}

abcMeans with different superscripts within the same raw are different $(P<0.05), \quad{ }^{1} \mathrm{~kg}$ milk/kg BW of suckling lambs

Milk conversion ratio ( $\mathrm{kg}$ milk/kg growth of suckling lambs) was almost not variable with the only difference $(P<0.05)$ was observed for the $5 \%$ SFO group, and for the $5 \%$ SBO group when taking about male lambs ratio. Such variations were due to differences observed in male lambs as the ratio was not different among female lambs. Differences in milk conversion ratio could be justified due to differences in milk yield or milk fat content. The higher ADG of male lambs in the present study compared to females would mostly be due to the fact that males usually have higher weights and though higher gain.

Changes in performance of suckling lambs are mainly related to differences in milk yield, as well as milk fat and protein levels (Manso et al. 2011). In our case, lambs were fed exclusively with maternal milk with no limiting for suckling which would explain the lack of effect on lamb performance. 
Cholesterol was increased $(P<0.05)$ with SBO level but decreased $(P<0.05)$ with SFO (Table 4). On the other hand, blood triglycerides were reduced by oil supplements regardless of the oil source. Usually, providing fats in the diet promotes the production of lipoproteins in the intestine; the major site of de novo cholesterol synthesis in ruminants which would most probably be the reason behind the observed increase in serum cholesterol levels (Espinoza et al. 1997). On the other hand, fat rich in PUFA reduces the lipolysis in the body and thus leads to lower plasma levels of not esterified fatty acids (NEFA), which subsequently would lead to lower levels of triglycerides (Sanz Sampelayo et al. 2006).

Both metabolites have been closely linked to other fat parameters in the body like low density lipoprotein, high density lipoproteins and very low density lipoproteins in lambs (Espinoza et al. 1997) which indicates that such changes in these parameters would affect the quality of the meat obtained from these lambs.

\section{Milk fatty acid profile}

No effect was reported on C4:0 and C6:0 FAs among treatments. Meanwhile, C8:0 was increased $(P<0.05)$ with $3 \%$ SFO supplementation, while C10:0 was reduced $(P<0.05)$ with both oils (Table 5). Medium chain FAs (C12:0-C15:0) also had similar trend either not to change or to decrease. Usually, short chain FA concentrations are either unchanged or only slightly reduced by increased lipid supplementation in the diet (Chilliard et al. 2003, Zhang et al. 2006a, Gómes-Cortés et al. 2008, Castro et al. 2009, Toral et al. 2010). However, the reason for the increase observed in the C8 content could be due to an unclear physiological reason.

Table 5

Fatty acid profile (\% of identified FAs) and conjugated linoleic acid content of milk from Awassi ewes fed different levels of SBO or SFO in their rations

\begin{tabular}{|c|c|c|c|c|c|c|}
\hline & Control & $3 \%$ SBO & $5 \%$ SBO & $3 \%$ SFO & $5 \%$ SFO & SEM \\
\hline C4:0 & 2.68 & 2.00 & 2.56 & 2.57 & 1.77 & 0.48 \\
\hline C6:0 & 2.67 & 2.22 & 2.46 & 2.88 & 2.68 & 0.33 \\
\hline C8:0 & $2.61^{b c}$ & $2.67^{\mathrm{b}}$ & $2.27^{c}$ & $3.12^{\mathrm{a}}$ & $2.12^{c}$ & 0.17 \\
\hline $\mathrm{C} 10: 0$ & $9.14^{\mathrm{a}}$ & $7.34^{c}$ & $6.99^{c}$ & $8.51^{\mathrm{b}}$ & $7.53^{b c}$ & 0.36 \\
\hline C12:0 & $4.04^{\mathrm{a}}$ & $3.04^{b c}$ & $2.81^{c}$ & $3.31^{b}$ & $3.01^{c}$ & 0.13 \\
\hline $\mathrm{C} 14: 0$ & $8.12^{\mathrm{ab}}$ & $8.48^{\mathrm{a}}$ & $7.58^{b}$ & $8.00^{\mathrm{ab}}$ & $7.64^{b}$ & 0.34 \\
\hline C14:1 & 0.11 & 0.10 & 0.09 & 0.17 & 0.07 & 0.05 \\
\hline C15:0 & 0.62 & 0.55 & 0.49 & 0.60 & 0.49 & 0.08 \\
\hline $\mathrm{C} 16: 0$ & $27.27^{\mathrm{ab}}$ & $28.65^{\mathrm{a}}$ & $28.02^{\mathrm{a}}$ & $26.06^{b}$ & $28.45^{\mathrm{a}}$ & 0.69 \\
\hline $\mathrm{C} 17: 0$ & 0.58 & 0.61 & 0.56 & 0.61 & 0.58 & 0.04 \\
\hline C17:1 & $0.67^{a}$ & $0.58^{\mathrm{a}}$ & $0.53^{c}$ & $0.63^{\mathrm{ab}}$ & $0.66^{\mathrm{a}}$ & 0.02 \\
\hline C18:0 & $11.04^{b}$ & $11.81^{\mathrm{ab}}$ & $12.65^{\mathrm{a}}$ & $12.24^{\mathrm{ab}}$ & $11.50^{\mathrm{b}}$ & 0.49 \\
\hline${ }_{c 9} \mathrm{C} 18: 1$ & 25.86 & 26.61 & 27.73 & 26.16 & 27.06 & 1.03 \\
\hline${ }_{t 10} \mathrm{C} 18: 1$ & $0.38^{c}$ & $0.52^{\mathrm{b}}$ & $0.60^{\mathrm{a}}$ & $0.58^{\mathrm{ab}}$ & $0.62^{\mathrm{a}}$ & 0.03 \\
\hline${ }_{t 11} \mathrm{C} 18: 1$ & $0.90^{\mathrm{d}}$ & $1.80^{\mathrm{b}}$ & $1.56^{c}$ & $1.78^{b}$ & $1.96^{\mathrm{a}}$ & 0.06 \\
\hline$c 9,12 \mathrm{C} 18: 2_{\mathrm{n}-6}$ & 1.90 & 1.77 & 1.80 & 1.91 & 1.87 & 0.09 \\
\hline C18:3 $3_{n-3}$ & $0.56^{\mathrm{a}}$ & $0.46^{\mathrm{ab}}$ & $0.40^{\mathrm{b}}$ & $0.48^{\mathrm{ab}}$ & $0.47^{\mathrm{ab}}$ & 0.07 \\
\hline$C 20: 0^{n-3}$ & 0.17 & 0.16 & 0.09 & 0.21 & 0.07 & 0.05 \\
\hline \multicolumn{7}{|c|}{ Conjugated linoleic acid (CLA) } \\
\hline $\mathrm{c} 9, \mathrm{t} 11$ & $0.46^{d}$ & $0.55^{c}$ & $0.72^{\mathrm{b}}$ & $1.00^{\mathrm{a}}$ & $0.82^{\mathrm{ab}}$ & 0.09 \\
\hline $\mathrm{t} 10, \mathrm{c} 12$ & $0.19^{\mathrm{a}}$ & $0.05^{\mathrm{ab}}$ & $0.01^{b}$ & $0.14^{\mathrm{ab}}$ & $0.06^{\mathrm{ab}}$ & 0.07 \\
\hline Both & $0.65^{\mathrm{b}}$ & $0.60^{\mathrm{b}}$ & $0.73^{\mathrm{ab}}$ & $1.14^{\mathrm{a}}$ & $0.88^{\mathrm{a}}$ & 0.09 \\
\hline
\end{tabular}

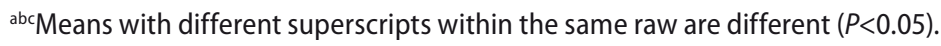


This would probably be due to the potential inhibitory effect of the dietary PUFA or its intermediates on de novo FA synthesis in the mammary gland or a dilution effect (Toral et al. 2010). These fatty acids are synthesised from acetate and $B$-hydroxybutyrate in the mammary gland and when long chain fatty acids $(\geq 18 C)$; especially those more unsaturated, from the feed are added to the ration, it will inhibit synthesis of acetyl-CoA carboxylase, thus decreasing the de novo synthesis in mammary gland (Manso et al. 2011). In our study, this change in short and medium FAs does not seem to be attributed to dilution, as the fat content in the milk remained unchanged.

C18:0 was only increased $(P<0.05)$ in milk of ewes with $5 \%$ SBO supplementation, while trans-isomers of $C 18: 1$ were both increased $(P<0.05)$ with oil source and level in the milk of supplemented ewes. Feeding unprotected oils increases C18:0 and mainly C18:1 leading to both total and partial hydrogenation of unsaturated FAs taking place in the rumen and probably a large extent to unidentified trans-isomers of C18:1 (Chilliard et al. 2003). The increased C18:0 levels in ewe milk supplemented with SBO would be the result of total rumen biohydrogenation of a part of the C18:2 ${ }_{\mathrm{n}-6}$ of the diet (Zhang et al. 2006a, Gómes-Cortés et al. 2008). However, the failure to notice a great increase in the proportion of C18:0 in the present case would most likely be due to the activity of the $\Delta 9$-desaturase enzyme which converts C18:0 derived from oil supplementation into C18:1 within the mammary gland (Castro et al. 2009).

At the same time, the increase of C18:1 fatty acids observed in the milk of ewes given the oil diets compared with those in the milk of control ewes may partly be due to the fact that oil supplements might have caused more incomplete biohydrogenation of $C 18: 2_{n-6}$ and C18:3 ${ }_{n-3}$ fatty acids in the rumen and/ or the action of $\Delta^{9-}$ desaturase enzyme in the mammary gland over a portion of the C18:0 generated in the rumen (Zhang et al. 2006a, b). Feeding fat supplements rich in PUFAs has been found to increase milk content of C18:3 in ewes, does and cows (Zhang et al. 2006b).

Cis-9, trans-11 conjugated linoleic acid (CLA) level was increased $(P<0.05)$ with oil treatment compared to control ewes and with a trend of higher values for SFO over SBO. Meanwhile, the trans-10, cis-12-CLA values were almost not different among different groups. The concentration of both CLA isomers in milk was also higher $(P<0.05)$ for both SFO groups compared to other groups.

Cis-9 trans-11 CLA is the most common CLA isomer and differences in CLA concentrations between oil treatments can be attributed to the fact that CLA is an intermediate product in the biohydrogenation process of C18:2 cis-9 cis-12 (linoleic acid) which is present in higher concentration in SFO (Zhang et al. 2006a, Castro et al. 2009). The cis-9 trans-11 CLA content of milk fat comes in part from the ruminal biohydrogenation of linoleic acid and is produced in part by $\Delta^{9}$-desaturase activity from C18:1 trans-11 (Gómes-Cortés et al. 2008, Castro et al. 2009). According to Zhang et al. (2006a), the reason behind that increase in CLA milk concentration was due to the precursors of CLA, C18:2 and C18:3, found in oil converted to CLA by rumen bacteria or endogenously tissue desaturation of C18:1 of rumen origin.

Other studies noted an increase in cis-9 trans-11 CLA content in milk fat after supplementing diets with oils rich in PUFA in ewes fed linseed and sunflower oils, in goats consuming linseed and sunflower oils and in goats consuming soybean oil (Castro et al. 2009). Soybean oil fed ewes displayed a nearly five-fold higher proportion of cis-9, trans-11 CLA (Manso et al. 2011). 
Based on relationships published for dairy cows, the increases in proportions of trans-10 C18:1 observed in the milk fat of ewes in this study would be expected to be associated with a decrease in milk fat concentration (know as milk fat depression, MFD), as it has been identified as a potential inhibitor of milk fat synthesis (Reynolds et al. 2006). In this trial, the oil supplement did not induce MFD (Table 2). Previous studies in ewes have shown that oil supplementation resulting in similar concentrations did not cause MFD and there is evidence that regulation of milk fat synthesis differs between the species (Hervás et al. 2008, Toral et al. 2010). Diets with a vegetable oil supplement must induce changes in ruminal fermentation in order to cause a significant reduction in fat synthesis (Castro et al. 2009). Our study used moderate levels of both oils, which probably did not upset the ruminal environment. Although the reasons for these different responses are still uncertain, some authors have reported that lactating sheep might be less sensitive than cows to some MFD-inducing factors, such as high concentrate diets, probably because of their ability to maintain normal rumen function (Toral et al. 2010). However, as described in this study and proposed by Manso et al. (2011), the addition of free oils instead of intact seeds seems to be more efficient for increasing the concentrations of healthy intermediaries in milk, such as cis-9, trans-11 CLA and 18:1trans-11, as well as those FAs that are more plentiful in the different oils added to the ewe diets.

\section{Blood fatty acid profile}

Short (C4:0-C10:0) and medium (C12:0-C15:0) chain fatty acids were mostly not changed among treatments due to oil supplementation (Table 6). On the other hand, long chain FA in the plasma of suckling lambs were mostly increased $(P<0.05)$ following oil supplementation with no clear effect for the source or level. C18:1 trans isomers in the plasma were increased $(P<0.05)$ with oil supplementation.

It is hard to compare present findings with others as available data about the full fatty acid profile in the blood serum of lambs are very scarce. However, such results of the serum FA profile would mostly reflect those of the milk FAs of dams (Lurueña-Martinez et al. 2010). According to Berthelot et al. (2012), FA composition of muscle and adipose tissues in suckling lambs or kids depends on the milk FA profile which is strongly related to the composition of the diet of their dams with a greater change occurring after weaning. Sanz Sampelayo et al. (2006) found that when supplementing the diets of dam goats with a fat source, the FA composition in the tissue fat of suckling kids was almost alike to that of their dams' milk FA composition.

Again, the concentration of the short and medium chain FA concentrations (C4:0-C15:0) are classically either unchanged or only slightly reduced by increased lipid supplementation in the diet or body lipid mobilisation (Chilliard \& Ferlay 2004).

Concentration of the cis-9, trans-11 CLA was not affected with oil treatment. Meanwhile, the trans-10, cis-12 isomer was increased $(P<0.05)$ with oil tratment regardless of oil source or level. The same was also observed in the sum of the two CLA isomers studied herein.

Concentrations of cis-9, trans-11 CLA and sum of both isomers in the blood, like that of milk, were affected by oil treatment. The increased CLA concentration in muscle tissues of suckling kids was accompanied by increased CLA in the milk of their dams (Sanz Sampelayo et al. 2006). The sucking lamb, with no access to long fibre, effectively functions as a monogastric; 
therefore, fatty acids absorbed in the small intestine are not subject for modification by ruminal bacteria. As a consequence, the presence of C18:1 trans-11 and cis-9, trans-11 CLA within sucking lamb plasma must have resulted either from the secretion of these fatty acids into maternal milk or the action of $\Delta^{9}$-desaturase (Capper et al. 2007). Indeed, they proposed that the increased concentration of cis-9, trans-11 CLA in muscle of lambs born by ewes selected for high cis-9, trans-11 CLA in milk fat was due to the desaturation of C18:1 rather than due to the up-regulation of $\Delta^{9}$-desaturase in mammary or muscle tissue.

Table 6

Fatty acid profile (\% of identified FAs) and conjugated linoleic acid content of blood from lambs of Awassi ewes fed different levels of SBO or SFO in their rations

\begin{tabular}{|c|c|c|c|c|c|c|}
\hline & Control & $3 \%$ SBO & $5 \%$ SBO & $3 \%$ SFO & $5 \%$ SFO & SEM \\
\hline C4:0 & 0.23 & 0.30 & 0.21 & 0.40 & 0.87 & 0.54 \\
\hline C6:0 & 1.11 & 2.38 & 1.45 & 2.43 & 2.10 & 0.82 \\
\hline C8:0 & 3.91 & 4.30 & 3.15 & 6.19 & 3.28 & 1.78 \\
\hline $\mathrm{C} 10: 0$ & $3.24^{\mathrm{a}}$ & $2.53^{\mathrm{ab}}$ & $1.98^{\mathrm{b}}$ & $2.47^{a b}$ & $1.97^{\mathrm{b}}$ & 0.57 \\
\hline $\mathrm{C} 12: 0$ & 2.74 & 2.42 & 1.84 & 1.80 & 1.76 & 0.58 \\
\hline C14:0 & $2.60^{\mathrm{a}}$ & $1.02^{c}$ & $2.08^{b}$ & $2.47^{\mathrm{ab}}$ & $2.15^{b}$ & 0.18 \\
\hline $\mathrm{C} 14: 1$ & $1.29^{c}$ & $3.43^{\mathrm{a}}$ & $3.25^{\mathrm{ab}}$ & $2.80^{\mathrm{a}}$ & $1.57^{\mathrm{b}}$ & 0.28 \\
\hline C15:0 & 1.24 & 2.42 & 1.84 & 1.80 & 1.78 & 0.58 \\
\hline $\mathrm{C} 16: 0$ & $16.37^{a}$ & $15.46^{b}$ & $13.57^{b}$ & $14.45^{b}$ & $13.63^{b}$ & 2.59 \\
\hline $\mathrm{C} 17: 0$ & 1.25 & 1.22 & 1.95 & 1.60 & 1.91 & 0.58 \\
\hline C17:1 & $0.88^{b c}$ & $1.06^{\mathrm{ab}}$ & $0.95^{b c}$ & $1.21^{\mathrm{a}}$ & $0.77^{c}$ & 0.11 \\
\hline C18:0 & $17.16^{a}$ & $16.14^{\mathrm{ab}}$ & $12.83^{\mathrm{b}}$ & $12.89^{b}$ & $13.52^{\mathrm{b}}$ & 2.07 \\
\hline${ }_{9} \mathrm{C} 18: 1$ & $14.69^{a}$ & $13.51^{\mathrm{b}}$ & $12.70^{\mathrm{b}}$ & $13.13^{b}$ & $16.04^{\mathrm{ab}}$ & 2.20 \\
\hline${ }_{t 10}^{C 9} \mathrm{C} 18: 1$ & $2.66^{d}$ & $4.39^{c}$ & $5.22^{\mathrm{b}}$ & $4.80^{\mathrm{bc}}$ & $6.00^{\mathrm{a}}$ & 0.21 \\
\hline${ }_{t 11}^{t 10} \mathrm{C} 18: 1$ & $1.87^{\mathrm{d}}$ & $4.01^{c}$ & $4.71^{\mathrm{a}}$ & $4.45^{b}$ & $4.23^{b c}$ & 0.11 \\
\hline${ }^{c 9,12} \mathrm{C} 18: 2_{n-6}$ & $18.01^{\mathrm{a}}$ & $11.22^{c}$ & $14.12^{\mathrm{b}}$ & $11.28^{d}$ & $11.92^{c}$ & 1.73 \\
\hline C18:12 ${ }^{c 9}{ }_{n-3}{ }^{n-6}$ & $2.02^{b}$ & $2.26^{b}$ & $4.61^{\mathrm{a}}$ & $2.10^{\mathrm{b}}$ & $2.67^{b}$ & 0.35 \\
\hline$C 20: 0^{n-3}$ & 3.36 & 3.83 & 5.09 & 4.30 & 6.23 & 1.45 \\
\hline \multicolumn{7}{|c|}{ Conjugated linoleic acid (CLA) } \\
\hline $\mathrm{c} 9, \mathrm{t} 11$ & 2.15 & 4.26 & 5.00 & 4.85 & 3.05 & 1.62 \\
\hline $\mathrm{t} 10, \mathrm{c} 12$ & $2.20^{\mathrm{b}}$ & $3.42^{\mathrm{ab}}$ & $4.02^{\mathrm{a}}$ & $4.53^{\mathrm{a}}$ & $4.52^{\mathrm{a}}$ & 0.76 \\
\hline Both & $4.35^{b}$ & $7.68^{a}$ & $9.02^{\mathrm{a}}$ & $9.38^{\mathrm{a}}$ & $7.57^{\mathrm{a}}$ & 1.02 \\
\hline
\end{tabular}

${ }^{\mathrm{abc} M e a n s}$ with different superscripts within the same raw are different $(P<0.05)$.

Comparison of the concentrations of CLA in sucking lamb plasma with the amounts supplied by maternal milk suggests that a system for the preferential conservation and deposition exists in animals with a habitually low preformed dietary supply.

In conclusion, these result demonstrated a considerable scope in manipulating the fatty acid composition of ewe milk with oil supplementation. The supplementation of a diet with SBO or SFO at different levels can also increase milk production. However, no effects were obtained on weaning weights of lambs for these ewes. Both oils also increased CLA in blood plasma of suckling lambs. Nevertheless, supplementation with SFO was more effective than that with SBO in increasing CLA concentration in milk fat. Feeding SFO could be a valuable tool for farmers who keep dairy sheep under intensive feeding system to produce milk and dairy products enriched in PUFA and CLA. 


\section{References}

AOAC (1995) Official Methods of Analysis of the Association of Official Analytical Chemists, 16th ed. AOAC, Gaithersburg, MD, USA

Baldi A, Cheli F, Corino C, Dell'Orto V, Polidori F (1991) Effects of feeding calcium salts of long chain fatty acids on milk yield, milk composition and plasma parameters of lactating goats. Small Rumin Res 6, 303-310

Berthelot V, Bas P, Pottier E, Normand J (2012) The effect of maternal linseed supplementation and/or lamb linseed supplementation on muscle and subcutaneous adipose tissue fatty acid composition of indoor lambs. Meat Sci 90, 548-557

Castro T, Manso T, Jimeno V, Del Alamo M, Mantecón AR (2009) Effects of dietary sources of vegetable fats on performance of dairy ewes and conjugated linoleic acid (CLA) in milk. Small Rumin Res 84, 47-53

Capper JL, Wilkinson RG, Mackenzie AM, Sinclair LA (2007) The effect of fish oil supplementation of pregnant and lactating ewes on milk production and lamb performance. Animal 1, 889-898

Chilliard Y, Ferlay A, Rouel J, Lamberet G (2003) A Review of Nutritional and Physiological Factors Affecting Goat Milk Lipid Synthesis and Lipolysis. J Dairy Sci 86, 1751-1770

Chilliard Y, Ferlay A (2004) Dietary lipids and forages interactions on cow and goat milk fatty acid composition and sensory properties. Reprod Nutr Dev 44, 467-492

Cieslak A, Kowalczyk J, Czauderna M, Potkanski A, Szumacher-Strabel M (2010) Enhancing unsaturated fatty acids in ewe's milk by feeding rapeseed or linseed oil. Czech J Anim Sci 55, 496-504

Espinoza JL, Ramirez-Godinez JA, Simental SS, Jiménez J, Ramirez R, Palacios A, De Lun R (1997) Effects of calcium soaps of fatty acids on serum hormones and lipid metabolites in Pelibuey ewes. Small Rumin Res 26, 61-68

Geohring HK, Van Soest PJ (1970) Forage fiber analyses, Agriculture Handbook No. 379. 3rd ed., Agriculture Research Service, USDA, Washington, DC, USA

Gómez-Cortés P, Frutos P, Mantecón AR, Juárez M, de la Fuente MA, Hervás G (2008) Milk Production, Conjugated Linoleic Acid Content, and In Vitro Ruminal Fermentation in Response to High Levels of Soybean Oil in Dairy Ewe Diet. J Dairy Sci 91, 1560-1569

Hervás G, Luna P, Mantecón AR, Castañares N, de la Fuente MA, Juárez M, Frutos P (2008) Effect of diet supplementation with sunflower oil on milk production, fatty acid profile and ruminal fermentation in lactating dairy ewes. J Dairy Res 75, 399-405

Loor JJ, Herbein JH, Jenkins TC (2002) Nutrient digestion, biohydrogenation, and fatty acid profiles in blood plasma and milk fat from lactating Holstein cows fed canola oil or canolamide. Anim Feed Sci Technol 97, 65-82

Lurueña-Martínez MA, Palacios C, Vivar-Quintana AM, Revilla I (2010) Effect of the addition of calcium soap to ewes' diet on fatty acid composition of ewe milk and subcutaneous fat of suckling lambs reared on ewe milk. Meat Sci 84, 677-683

Manso T, Bodas R, Vieira C, Mantecón AR, Castro T (2011) Feeding vegetable oils to lactating ewes modifies the fatty acid profile of suckling lambs. Animal 5, 1659-1667

NRC (2007) Nutrient Requirements of Small Ruminants. Sheep, Goats, Cervids, and New World Camelids. National Academy Press. Washington, DC, USA

Reynolds CK, Cannon VL, Loerch SC (2006) Effects of forage source and supplementation with soybean and marine algal oil on milk fatty acid composition of ewes. Anim Feed Sci Technol 131 SI, 333-357

Sanz Sampelayo MR, Fernández JR, Ramos E, Hermoso R, Gil Extremera F, Boza J (2006) Effect of providing a polyunsaturated fatty acid-rich protected fat to lactating goats on growth and body composition of suckling goat kids. Anim Sci 82, 337-344

Steel GDR, Torrie HJ (1980) Principles and Procedures of Statistics. 2nd ed., McGrow Hill, New York, USA

Toral PG, Frutos P, Hervás G, Gómez-Cortés P, Juárez M, de la Fuente MA (2010) Changes in milk fatty acid profile and animal performance in response to fish oil supplementation, alone or in combination with sunflower oil, in dairy ewes. J Dairy Sci 93, 1604-1615 
Zhang RH, Mustafa AF, Zhao X (2006a) Effect of feeding oilseeds rich in linoleic and linolenic fatty acids to lactating ewes on cheese yield and on fatty acid composition of milk and cheese. Anim Feed Sci Technol $127,220-233$

Zhang R, Mustafa AF, Zhao X (2006b) Effects of flaxseed supplementation to lactating ewes on milk composition, cheese yield, and fatty acid composition of milk and cheese. Small Rumin Res 63, 233-241 